\title{
I Don't Make Objects, I Make Projects: Selling Things and Selling Selves in Contemporary Artmaking
}

working paper / draft 2016.08.03

\author{
Alison Gerber \\ Department of Social and Economic Geography \\ Uppsala University \\ alison.gerber@kultgeog.uu.se \\ Clayton Childress \\ Department of Sociology \\ University of Toronto \\ cchildress@utsc.utoronto.ca
}

\begin{abstract}
What role do artists play in the valuation of their activities? Theoretical perspectives on art have assumed that such value is closely linked to the prices of art objects and have minimized the place of content providers in the creation and definition of value. Through analysis of the writings of American, Canadian, and Swedish artists from 1967-2015, we find that artists themselves can drive institutional changes within cultural arenas, moving discursively from an object-oriented market logic to a market based in the provision of services. Our findings suggest new ways to look at extant literature: 1) dominant theories treat artists as either structurally or intentionally insulated from the pricing of their work, while we show how artists act to define the value of artistic practice; 2) we show how terminology may remain stable while underlying meanings and institutionalized strategies aimed toward the accomplishment of goals evolve, and argue for the analysis of discursive practices beyond the search for stability or change in the usage of key terms; and finally, 3) we argue that analysts should look beyond price when aiming to understand the valuation of artistic practice.
\end{abstract}

What is the basis of the value of market work, and how is it established in the contemporary art world? Since Hirsch (1972) and Becker (1982), the sociological study of culture industries has assumed that content creators like visual artists are minimally involved in defining and establishing value. In these perspectives, artists are acted upon by systems of conventions in order to get things done (as in Becker 1982), or by industry, organizational and market constraints (see Anand and Peterson 2004 for review). Visual artists are, in these dominant theoretical paradigms, decoupled from the "business" side of art markets, and sometimes intentionally so. More recent perspectives, particularly those that follow Viviana 
Zelizer in challenging "hostile worlds" approaches (Zelizer 2000), question such assumptions but continue to focus on the roles and accounts of organizational actors in pricing (Fine 2003; Gibbon 1987; Velthuis 2003, 2005). Yet there are strong reasons to suspect that artists themselves play a role in defining the value of their work. This paper examines changes in the valuation of visual art across two time periods: from the 1960s through late 1970s and from the 1980s to the present. Despite increasing cultural and legal support for their position as producers of physical and intellectual property, over this time artists' talk with regards to the valuation of their own practice shifts from an emphasis on products to an emphasis on service provision. Our findings suggest that artists play a more active role in the valuation processes of artistic activities than has been traditionally assumed; further, we show that shifting logics within communities of cultural creators can have wider effects on valuation practices across art worlds.

This paper looks to public statements made by American, Canadian, and Swedish visual artists engaged in some form of advocacy for artists as workers from 1967 to 2015, with special attention to conversations taking place around five organizations: Canadian Artists' Representation; Art Workers Coalition; Working Artists and the Greater Economy; the Swedish Artists' National Organization; and the Institute for Artists and Art Mediators. These organizations serve as sites of focused and extensive discussions about art as work. We show that while artists' practices have remained relatively stable, their claims regarding the value of those practices have shifted: they have turned from an emphasis on the value of material products to a focus on the provision of services and the value of such services. Artmaking looks much the same in these three national contexts as it did forty years ago: artists mostly continue to make things and either show or sell them to others in gallery settings. Against that stable backdrop, 
however, we show that visual artists have actively reconstructed the tasks, meanings, and value of visual art work.

\section{Artists as workers}

In classical social theory, artists figure as romantics who hope to avoid the conventional constraints of working life (Arendt 1998:127-29; Durkheim 1984:13; Weber 1968:191). Contra this typification, empirical evidence dating back to the early modern era of painting and sculpture show that artists have long felt otherwise (Bradley and Esche 2007; Bryan-Wilson 2009; Harrison and Wood 2003). Recent sociology, rather than treating artists as isolated geniuses, has situated them in complex webs of social relations based on competition in fields (Bourdieu 1993), cooperation in worlds (Becker 1982) or constraints in industries (Peterson and Anand 2004). As White and White (1965), Lang and Lang (1988), Battani (1999), and Menger (2014) have shown, artists are less romantic, and less elusive and unknowable than early social theories made them.

Despite these advances, in the most prominent sociological theories of the arts artists, for the most part, are actively separated from such base concerns as valuation and pricing. Instead, the valuation of artists' work is treated as a form of "humdrum" labor (as distinct from creative labor (Caves 2000)) that is engaged in by support personnel who price artistic objects according to standardized conventions reflected through size, materials, the reputations of their representatives, and so on (Becker 1982; Velthius 2013). In these industry-centered views, due to the massive oversupply of artists hoping to gain entrance by selling their art through organizations which must winnow down and "pick winners" for representation (Hirsch 1972; 
Menger 1999), we would expect insurmountable coordination problems between artists who, as a loosely coupled collection of individuals, would be reactive to market shifts in valuation rather than advocating for or driving them.

Despite the traditional treatment of artists first as autonomously artistic and later as shielded from humdrum work, in general, being a serious artist generally entails considering art "work," a "job," a "profession," and artists speak of their practice as such (Bain 2005). Studies on artists as professionals have found that while artists' professional status is problematic for researchers, it is a relatively unproblematic position for artists themselves, who tend to have a strong professional identity and often have high levels of education and other features of the professions (Bryan-Wilson 2009; Singerman 1999; Markusen 2013). The conversations about art-as-work considered here emerge out of a long tradition in the art world that has gone without adequate attention in the literature.

Studies of occupational legitimacy show clearly that individuals, like organizations, are deeply involved in legitimizing their occupations and promoting the value of their products and services (Berman 2006; Fine 1996; Sherman 2010); artists are not immune to this need, and the data below reflects their active participation in processes of legitimation that may be especially important for artists without stable employment. In a field like the arts, where many make a living at art and related professions but many more do not, such legitimization might be especially complex as well as particularly important to practitioners.

In this view, rather than being dependents who cannot coordinate their actions, artists are workers with occupational identities who embed themselves within organizations and can coordinate to drive a shift in cognitive orientations as to what constitutes "work" for artists, and how it should be valued. The institutional logics literature, building off of Friedland and Alford 
(1991; although see Thornton, Ocassio and Lounsbury 2012 for review) has documented these cognitive shifts in orientation both within cultural arenas like academic publishing (Thornton and Ocasio 1999), architecture (Jones and Livne-Tarandach 2008; Thornton, Jones and Kury 2005) and nouvelle cuisine (Rao, Monand and Duran 2003) and beyond them. As artists, as collective actors, shift from an object-based logic to a time-based logic, they make agentic and normative claims by questioning "what is legitimate, which issues and problems deserve attention, and what solutions and answers are appropriate," and shift both symbolic orientations and rule structures in the process (Thornton 2004: 13-14).

Studies in economic sociology concerned with issues of value in social life, especially those focused on monetary valuation, orient this paper's analysis. Zelizer has shown how fluidly economic ideas interact with others and has investigated monetary valuation in varied fields (e.g. Zelizer 1978, 1981, 1989). This study is guided by contemporary authors investigating questions of value in varied fields: bodily and genetic material (Almeling 2007; Anteby 2010; Healy 2006); care and intimate work (Bernstein 2007; Macdonald 2010); and nature itself (Fourcade 2011). All of these analyses show how market norms interact with others, and suggest routes to and away from market valuation. A few studies look to artists in order to illuminate broader issues of valuation, but tend to focus on market prices for objects (Cowen and Tabarrok 2000; Velthuis 2003, 2004, 2005). In doing so, they look past the activities of the great number of artists working outside or largely outside of the market for objects - those who make a living with teaching jobs, as studio assistants, as commercial artists; those hopping from residency to residency and grant to grant; those subsidizing their practice with a "day job," an inheritance, or a partner's income. 
Those making a living outside of the primary market for art objects are certainly the greater proportion of those working in the visual arts, and so an understanding of artists and artistic practice must consider market prices as only one piece of a complex puzzle. This is true not only for artists, of course; think of the varied ways to calculate the value of a stay-at-home parent, the many reference points and commensurations involved. Drawing from the literature on institutional logics to consider the transition from an object-centered market logic to a timebased logic, we show that artists actively and agentically consider art-making at its intersection with financial remuneration. Remuneration, in fact, orients artists' sense of worth for their activities. As their arguments about the value of the things they did changed, so too has their sense of what makes artistic practice "worth doing."

\section{Methods}

This paper uses interpretive analysis of public statements made by individual visual artists on the topic of the artist as worker, often as advocacy related to artists' grassroots organizations and unions, from 1967 through 2015. We consider artists engaged in discussion about appropriate remuneration. They represent a transnational conversation in contemporary artmaking, and they argue that they speak for artists generally, whether they are members of an artists' organization or not.

We began our data collection in 1967 in order to capture a wave of activity in and around formal and informal organizations beginning that year and continuing through approximately 1971. This time period is important in both in practical and art historical terms, including the rise and fall of the Art Workers Coalition in New York City, the development of Canadian Artists' 
Representation, and major changes in the leadership and direction of the Swedish Artists' National Organization. "Visual artist" here refers to those for whom visual art ('fine' or 'contemporary' sculpture, painting, drawing, printmaking, photography, video, performance, etc) is a primary occupation. These artists are generally engaged in, or aspire to engage in, the world of high contemporary art; they consider themselves to be fully engaged in an art world - in their experience, the art world - as "serious," "professional" artists with an occupational commitment to art practice, regardless of the fact that many have little or no income from their art practice and may be engaged in parallel careers. If we are to use Becker's typology, this is a world of "integrated professionals" and "mavericks" who inhabit, or aspire to inhabit, the international contemporary art market characterized by exhibitions at contemporary art museums, art fairs, high-end commercial galleries, and art centers (Becker 1982). While this necessarily excludes "folk" and "naïve" artists from the analysis, it is in convention with recent studies of valuation and pricing in art worlds (e.g. Velthuis 2003), and centers the analysis on artists who in extant models of cultural creation and production should be most reactive to organizational and institutional pressures but are seen here to be coordinating and making their own institutional demands about what constitutes work. Our findings are necessarily influenced by the context in which artists' statements are made. While artists do regularly talk about art as work, they do not always do so; these statements are part of a specific conversation within the art world, and there are others.

This analysis began as a grounded inquiry (Glaser \& Strauss, 1967; Miles and Huberman, 1994) into questions of artists as workers and of unionization and professionalization, focusing on two North American artists' organizations: Canadian Artists' Representation and the shortlived Art Workers Coalition. Primary documents were coded and through an iterative process 
themes emerged and were revised, and over time questions of valuation became paramount. As the project progressed materials related to additional artists' organizations was incorporated, chosen to provide national and organizational diversity. The artists considered here are largely members of, leaders of, or antagonistic toward: in Canada, Canadian Artists' Representation (1968-present); in the United States, Art Workers Coalition (1969-1972) and Working Artists and the Greater Economy (2008-present); and, in Sweden, the Swedish Artists' National Organization (1937-present) and the Institute for Artists and Art Mediators (2003-2009). In some organizations, there was almost total generational and individual replacement over time, while in others, founding members continue to maintain strong voices in the organization for decades. For each of these organizations we read all published material available from the years of interest - thousands of pages of newsletters, posters, editorials, and other materials. Only relevant material was coded. Organizations and artists' groups showed themselves to be useful as sites of ongoing, concentrated national and transnational discussion about artists as workers and remuneration, though individual artists entirely unaffiliated with organizations are also represented in the data below when their statements were incorporated into the transnational discussion.

It is important to note that no cross-national comparison is made here; rather, we incorporate artists practicing in three countries in order to illuminate broadly shared cultural structures and bracket out regional variation. There are significant differences between the experience of practicing artists in the three countries considered here, but on the issues considered in this study there is remarkable similarity between the three national contexts. Differences concern local strategies rather than divergent meanings. Artistic practice has, for the duration of this study, been globalised and has included for many a good deal of travel and 
international exchange, and ideas and individuals move easily between these three countries. Thanks to differences in local, national, and regional cultural and institutional contexts, the data includes a good deal of only local concern, and the use of data from a transnational context allowed for the bracketing of such specifically local issues. For the purposes of this study only discussions that are present in all three contexts are included below.

We found, as have other authors, that since all texts considered were first-person statements that might in another context be called "opinion pieces" they were relatively straightforward to code and rarely inconsistent (Binder 1993). Using a grounded theory approach, the iterative processes of analysis ultimately resulted in 20 major codes, which were folded into four families. These four families reflected how artists thought about themselves as workers, two distinct understandings of the value of artwork - as based in objects and, later, in services - and changing ideas of the term "services". The first family of codes reflects artists' sense of themselves as workers, as discussed above and well documented in other studies. We focus below on the second through fourth families of codes, on artists' changing sense of the value of their activities over time, and use the changing notion of "services" to illustrate the ways that apparently stable language masks significant change.

\section{Artists making things}

In the first part of the period considered here - the 1960s through late 1970s - artists argued that the value resulting from their work resided in the multiple uses of the products that they created and distributed. The "job" of being an artist as it was imagined was one in which artists make things that have value; the core tasks involve production and distribution. This argument 
developed over several decades. While it is no longer the dominant logic by which artists value their work, it is still instrumentalized by artists in efforts to enforce copyright law, create new copyright provisions, and to obtain royalties and resale rights. During the 1960s and 70s, however, this was the dominant, almost singular logic by which artists operated. For example, in 1967 a Canadian artist wrote that

The painting or sculpture etc. is a MATERIA PRIMA, the raw product from which many business concerns derive profit [...] The artists should be the first to benefit from his own work in this process but in fact, he has no place in the present arrangement. (Frutkin 1987:2)

Proposals from 1969 in the United States demand that "the museum, collector or publication would compensate the artist for use of his art" (Lewitt 1969:54). In a 1973 newsletter, a group of artists in Canada describe the aims of an organization they are trying to start as "to uncover the means, implicit in the works themselves, for providing revenue to the practicing artist [...] there are various means of recovering income inherent in the works themselves" (Chambers et al. 1973:2) This letter continues with a call for exhibition fees, colloquially referred to here and elsewhere as "rental fees.” (Chambers 1973:38; Perreault 1969:120; Tateishi 1985:4) The belief that the value artists produced lay in the objects they produced led artists to argue primarily for better copyright provisions; they argued extensively for both reproduction and exhibition royalties.

Artists conceptualized their practice as being based in the provision of objects for use objects that consisted of both physical and intellectual property. Artworks are regularly referred 
to as a "resource", an object that has value. (Canadian Artists' Representation 1975a). Copyright provisions were seen as the key both to artists' control over their own work and to reimbursement for their efforts, and enforcement of existing law and expansion of copyright law were seen by the vast majority as appropriate goals in defining the value of artistic labor.

Demands were made in two arenas in particular: artists demanded control over reproductions of their work, operationalized as royalty payments, as well as rental fees when their works were shown whether or not the work had been sold.

The demand for control over reproductions was, relatively speaking, straightforward: in most cases, it involved only enforcement of existing law. In 1969, an American artist suggests that artworks are primarily intellectual property: he argues that artworks are like manuscripts for popular novels; after purchasing the work, "the owner can keep it, or show it to his friends, but the artist continues to hold the rights of reproduction, including the right to collect royalties if he wants them" (Gordy 1969:98). The argument for rental fees was seen as an extension of the logics behind reproduction royalties, and terms like "royalties", "rental fees," and "exhibition fees" were interchangeable. The aforementioned proposal from that year suggests that, as artworks are both physical and intellectual properties, artists should be compensated for their use even after sale: "this is a rental, beyond the original purchase price... the principle of a royalty would be used." (Lewitt 1969:54). This author, like many others, hoped that even after the sale of an artwork the artist would be entitled to some measure of control over the artwork and payment for its use. In 1971, a Swedish artist argued simply in a speech during a union demonstration that "The artist should be given an exhibition fee for the right to use the work" (Suttner 1971a:9). Another, ten years later and after significant changes in the union's leadership, that "full payment for constant access to the fruits of our labor" (Petré 1981:4) was both 
legitimate and necessary. These goals have since been attained to various degrees, most notably in Canada where the "exhibition right" was made law and moral rights were significantly expanded in 1987.

Well into the 1980s, artists were explaining to other artists that the work they did was the creation of objects that had value. In an article from an artist's newsletter titled "Copyright - the Profitable Practice of Protecting Your Right," a Canadian artist explains copyright law in explicit terms:

When an artist creates an original work of art, s/he really creates two separate and distinct pieces of property. One is the work of art itself, which the artist may sell, trade or otherwise dispose of as desired. The second property is the copyright, or right to reproduce the work of art [...] stop thinking of copyright as valueless and unimportant. Make it a commodity separate from the work itself in your own mind, then treat it with the care and consideration that you would give any valuable property that you own. (Amundson 1982:10)

Such explanations were apparently still necessary and in-demand as part of artists' professional education. Thirty years later, however, artists' writings reflect a very different understanding: a Canadian artist writes that that "[rental] fees are meant to partially compensate for the time and cost of the production of the actual art works. Artists are not compensated for the preparation costs" (Beveridge 2005:5). A real shift was underway; artists, who had long argued that their core tasks revolved around the objects they produced, began slowly to view themselves as hourly workers, providing an as-yet-unacknowledged "service". That in this later period "preparation 
costs" should be considered on top of the rental fees for objects themselves signals a wider shift in how artists valued the time they dedicated to artistic labor in addition to the objects they created. While discussions of the provision of artistic services existed across both time periods, what constituted "services" and their relationship to value changed.

Services then, services now

Throughout the decades-long conversation considered here the words used change little, but their meaning changes significantly. The word "services" deserves special attention. A look at a single long-running artists' organization, CAR (later CARFAC), indicates that even within a single group - one with growing membership but the continuing engagement of founding members and single national context the meaning of "services" shifted in important ways between the 1970s and the present, despite real gains that should have served to solidify old ways of thinking.

Throughout the 1970s members of CAR argue that their basic principle is "fair exchange," which they further describe as "payment for services" that they instrumentalize, rationalize, and advocate for as rental fees; the "service" they provide is the provision of objects for rental. An example reads:

The fair-exchange principle is one which society already acknowledges for its multitude of dealings, and is simply understood as payment for services. Everyone performing a service in our society is paid in return. The cultural basis for society is created by artists; and we are agreeing with the rest of organized society that services do in fact require payment. Hence our suggested fee schedule (Chambers 1973:38). 
The fee schedule here is, of course, an outline of recommended rental fees for the provision of objects; "services" are not added to the fee schedule for another ten years. Artists in the 70s offering their "services" offered not their time or experience; they offered the temporary use of objects they had already made. Early CAR fee schedules include rental fees only: the first distributed schedule, in 1975, has "fees" for ten types of exhibition, from international oneperson exhibitions to local juried exhibitions offering less than $\$ 750$ in prize money. It closes: "This schedule relates to the work of all artists". It does not mention services, time, skills, or hours at all. (Canadian Artists' Representation 1975b). An artist writing a few years later remembered the early years of CAR quite simply: "We said, 'we would like rental fees,' and we explained the reason - everybody gets paid for their work.” (Crean et al. 1978). Artists did recognize some of the limitations of reliance on copyright by the late 1970s but saw this as a need for expanded notions of copyright rather than an argument for another model, as is clear from a brief presented by CAR in 1978 on new copyright legislation. The organization wrote:

"By temperament, logic, and product, the visual artist shares few, if any of the protective adaptations either in custom or legislation available to the author or composer. Even the largest series of "multiples" does not compare to an edition of an unsuccessful novel. Most often, a work of art is a single item. It can be sold but once, or as a very limited edition. [...] While on display, it can be seen, for free or a nominal fee. By any standard of comparison it can easily be seen that the visual artist is most vulnerable, and requires special and individual consideration in the reform of copyright law [...] Legislators must look behind the various rules in order to determine the underlying principles. When those 
principles are understood, it will then become clear why the visual artist is entitled to a public lending right, droit de suite, and stronger and broader remedies in cases of infringement." (Canadian Artists' Representation 1978)

Throughout the 1980s and 1990s, the organization remains concerned with artists' rights as the creators and owners of intellectual property. But as early as 1983, the first suggestions that artists' time might have value are visible, with the publication of the "Applebaum-Hebert Report", a federal cultural policy document that received wide attention in the Canadian artistic community. An artist writes, in translating the report to her contemporaries, "Canadian visual artists will not be surprised to learn that "the largest subsidy to the cultural life of Canada comes not from government, corporations or other patrons, but from the artists themselves, through their unpaid or underpaid labour." (Yates 1983:2) She notes that artists are described in the report as "highly specialized working poor" (Yates 1983:4). Later that same year, for the first time, "professional fees for consultations" are quietly introduced to CAR's fee schedule. The notion is finally present: artists' time is worth money, not only their products - but it is not yet widespread, and initially does not seem to resonate widely with artists or with CAR organizationally, though over the years artists slowly learned to bill for their time and expertise in exhibition negotiation, preparation, and installation, and in other situations where their "consultations" were of value, such as workshops and conferences. (Canadian Artists' Representation 1983). The strongest articulation of these ideas in the archive appear in 2005, in an editorial in the CAR newsletter strongly arguing for a notion of "services" that valued artists' time as well as their products. 
An argument that would not have been made in the 1970s was, in this later period, entirely rational and appropriate. We quote at length due to the clarity in expression of the point:

One area of work has rarely, if ever, been discussed: the unpaid labour artists contribute towards the preparation and installation of an exhibition. [...] Speaking as a professional artist, I calculated roughly the number of hours I typically spent on correspondence, supplying images and descriptions of works, writing statements and texts, negotiating terms and conditions, designing, consulting and working on the installation. I included hours spent packing and shipping the work, and everything else involved in getting and setting up an exhibition. [...] I estimated that 100 hours labour might be a reasonable average. The next question is the dollar value of this labour. A professional salary can run anywhere between $\$ 25$ and $\$ 125$ per hour. Since artists usually bottom out when it comes to pay, let's estimate 100 hours at $\$ 40$ per hour, i.e. $\$ 4,000$. On average, then, an artist subsidizes an exhibition to the tune of $\$ 4,000$ per exhibit. (Beveridge 2005)

It is notable that this artist does not argue that the time artists spend making their artwork - thinking, looking, constructing - should be included in this estimate, and his writing illustrates a central conflict among those in this latter period who advocate for the value of artists' time. This artist's strategy - to focus on administrative and logistical tasks done directly in service of an organization, to the exclusion of the majority of the tasks of artmaking - remains common today. Extant fees in this context - rental fees - as well as, presumably, sales, are understood by this author to 'cover' the artmaking time - though as noted here, such sales and rentals can only 
rarely be counted on for income - but not the time spent preparing for exhibitions, work now conceptualized as a form of "service".

Members of this organization made significant concrete gains over the past forty years among other things, they succeeded in pushing for changes to national copyright provisions that should have served to ensconce 1970s thinking in an institutional framework, strengthening artists' identities as the producers of objects and increasing incentives for artists to produce works that could be protected by copyright and to think of themselves as primarily producers of intellectual property. But even within this organization and national context, members came to argue that the "service" artists provide is no longer the provision of objects for purchase or rental; the "service" provided by artists today includes their time, the hours they spend in service to institutions that they consider employers.

Examples of these shifts abound outside of the Canadian context as well. In the United States an artist wrote in 1997 that "all artistic work, or labor, that is not compensated through the sale of a tangible product must be considered a form of service provision." (Fraser 1997:112). That text is today widely reproduced and well-known, and its author sits on the board of an artists' organization devoted to "establishing a sustainable labor relation between artists and the institutions that contract them." (Working Artists and the Greater Economy 2016). In Sweden in the early 1970s, artists' "cultural contribution" was understood as the production of exhibitions. An artist there argued explicitly that the primary "service" artists provide is the production of exhibitions, that fair pay comes in the form of attention to the objects that artists made and maintained intellectual property rights over (Suttner 1971a:7, 1971b:5). But by the 1990s in Sweden, artists were arguing that their practice had gone "from being primarily oriented toward the production of products to, to a much greater extent, being about skills, experiences, and other 
processes." (Ewald 2002:1) In 2004, an artist wrote a long debate article on the difference between rental fees and other forms of payment, arguing that the rental principle was not appropriate - that "what artists expect and demand payment for is their efforts, their labor", and suggests that a contract based in labor law - not copyright - regulating hourly payments is appropriate "when artists produce exhibitions on assignment" (Nordwall 2005:6). This language of producing exhibitions "on assignment" in service of institutions that request them has, by the mid-2000s, spread across the three national contexts considered here; artists use it to point out that they ask not for some kind of citizen's wage but, rather, ask simply for payment when their services are in demand by others.

Attention to the changing meaning of the word "services" shows clearly how radically artists reconceptualised the core, value, and tasks of their practice, even as the words they used remained stable. It has become reasonable for artists to see value in their time and to think of themselves as primarily service providers and only secondarily producers of objects; while they continue to ask for copyright protections and other benefits related to their material output, they now also think about the value of artistic practice differently, and instrumentalize new ideas in arguments for hourly wages.

Artists today are likely to argue that their time, and in particular the provision of services to clients who have requested them, is the element of their practice that has value. An American artist explains why she demands payment for her time, and like others she frames her demands as rational:

We're not asking for the world, we are asking simply to be paid for our labor. Museums want performance art for free? What do they think? That we dream it up while we are 
watching TV during the commercials? That's work. That's days, or weeks or months of work [...] We need our city's institutions, public and private, to take artists' labor into consideration when using it. We need to let them know that what is making their culture institution "rich" is the product of months or years of labor. (Hardy 2008)

Artists very rarely suggest that they have any special status, preferring instead to emphasize contributions to institutions that request their services - as, in the past, they focused on institutions that requested their products. A group of Swedish artists writes in an editorial:

We increasingly question the fact that, though we have the greatest role among all who work with exhibitions, our work is still not paid. Everyone else - directors, curators, technicians, guards, art handlers - who is a part of the work of an exhibition sees it as obvious that they should be paid for their work. Why is our work not valued in the same way? (Backman et al. 2006)

The 'work' here is that involved in mounting one exhibition - as above, the activities involved in making the artworks themselves are understood to be remunerated separately. The Canadian editorial considered above assigns a dollar value per hour to artists' labour and calculates the "subsidy" artists make to the state in the form of work on exhibitions (Beveridge 2005). A Swedish editorial from a few years later makes the same argument, here pointing to exhibitions at municipal galleries; artists "carry out unpaid work for the state and local governments worth 300 million crowns per year", their work "is in demand, but is not remunerated in proportion to the work carried out." (Reichert et al. 2007). When artistic practice 
as work is visualized as hourly labour on behalf of presenting institutions, artists ask not for copyright protections or resale rights but hourly pay, taxed and otherwise treated the same as other workers' wages and salaries. Three American artists write that they are simply "asking to be factored into our own equation, paid fees for honest work, to be equal participants in the economy." (Nguyen 2009). Artists working in the past decade are no longer likely to compare themselves to composers or writers - the owners of intellectual property - but instead reach to professional workers when they draw comparisons, comparing their skills and training to dentists and librarians. In 2006, two artists wrote in an editorial:

While artists.. represent a diverse professional demographic, they nonetheless share an acute understanding of the value of their time and skills... artists statistically have more education and training than the average Canadian worker but earn less than half the income. As Di Dabinett, a painter and textile artist, wryly noted, "I have as much professional training as a dentist - yet I earn one-eighth of what a dentist makes.” (Fleet \& Kemp 2006:6)

Another artist compared artists working in the public sector to the civil servants they worked alongside, pointing to the problems of receiving money but not a salary or wage:

All the library employees get a free flu shot because they are employees, but Dave Margoshes does not. [...] Library employees have a pension plan, paid sick days, workers' compensation and a variety of benefits that come from being a worker, and a member of a 
union. [...] Flu shots and who gets them is a small sign of a hidden reality: creators do not have much support and workers do. (Graham 2002:3)

Artists' practices changed relatively little over the past forty years; the language they used to make claims about themselves as workers remained largely stable as well. Artists speak of the value of their "services", their "work," throughout the period considered here. Close attention to artists' claims, however, shows that their sense of themselves as workers, and particularly the way that they promoted the value of their efforts, changed significantly over the past fifty years. This accounting and claims-making contributed to an evolving discussion of the value of art work.

\section{Conclusion}

Starting in the early 1980s, artists began to change the ways that they worked within the market order. Although their goals remained stable - remuneration for their labors, or "fair exchange", as they put it - their understanding of what constituted "fair exchange" shifted from an objectcentered to a time-, skill-, and service-based logic of market exchange in artistic activity. As artists saw new sites for the extraction of value from institutional partners they moved from an emphasis on property rights to a focus on the valuation of their time and skills, reconceptualizing themselves as service providers.

These findings suggest three new ways to reflect on extant literature. First, dominant theories of art-making and selling treat artists as creatives who are either structurally or intentionally insulated from the pricing of their work, but we show how artists themselves act to 
define the value of artistic practice. Second, the majority of literature on the valuation of art treats prices as appropriate proxies for the value of artistic labor. We argue that analysts should look beyond price when aiming to understand the valuation of artistic practice, and show how artists draw on multiple bases of value alongside objects and their properties. Finally, we argue for the analysis of discursive practices beyond the search for stability or change in the usage of key terms that are more traditionally captured in analyses of institutional logics. We show how terminology may remain stable while underlying meanings and institutionalized strategies aimed toward the accomplishment of goals evolve. We show how meanings can shift substantially over time, taking the contours and contents of institutional logics along with them.

The institutional logics literature suggests that changes to logics will lead to changing goals, but the case under consideration here suggests that goals may remain the same ("fair exchange") while ecological and cultural change has promoted evolution and change within the market logic in this field. In this case, changes to the meanings relevant to the market logics promoted a shift in appropriate means of attaining goals. A market practice once centered on the sale of property became, largely through the discursive efforts of artists, one in which an occupationalized vision of market work was laminated onto the older object-oriented discourse. Artists aiming to be remunerated for their efforts suddenly focused on the time they spent in service to institutions, rather than looking to develop and protect new forms of property - the exhibition rights, reproduction rights, and resale rights so important to earlier generations.

Social scientific analyses of art worlds that focus on gallery pricing leave open the question of whether and how artists themselves turn to such markets to define the value of their work. We know well that commercial galleries are not the only institutions presenting contemporary art, that much of the art seen by publics is housed outside of such galleries, and 
that an exclusive focus on commercial galleries and their pricing distorts our image of the art world (e.g. Favell 2012, Kwon 2004). The findings presented here support a perspective on contemporary art that looks beyond galleries and museums in describing the landscape of the art world, and that thinks beyond the pricing of art objects in investigations of value in order to accommodate immaterial bases of value and non-gallery markets.

From component parts to the hand of the artist, from the hand to the object, from the object to an hourly practice, and perhaps in the future a move from hourly services to salaries; all are converging on the image of a highly individuated professional who as an individual has particular value. Artists seem only to turn to the market for objects to define the value of their activities when they imagine themselves primarily as producers of objects; as their images of themselves shift, we can expect artists to continue to draw on alternative logics as they account for and promote the value of their work.

\section{Bibliography}

Almeling, Rene. 2007. "Selling Genes, Selling Gender: Egg Agencies, Sperm Banks, and the Medical Market in Genetic Material.” American Sociological Review 72(3):319-340. Amundson, Dale. 1982. "New York New York New York... Copyright and More from the CIAGP Conference in New York." CARFAC News, 10-11. Peterson, Richard A., and N. Anand. 2004. "The Production of Culture Perspective." Annual Review of Sociology 30:311-334.

Anteby, Michel. 2010. "Markets, Morals, and Practices of Trade: Jurisdictional Disputes in the U.S. Commerce in Cadavers.” Administrative Science Quarterly 55(4):606-638. Arendt, Hannah. 1998. The Human Condition. 2nd ed. Chicago: University of Chicago Press. Bain, Alison. 2005. "Constructing an artistic identity." Work, employment and society 19(1):2546.

Battani, Marshall. 1999. “Organizational Fields, Cultural Fields and Art Worlds: The Early Effort to Make Photographs and Make Photographers in the 19th-Century United States of America." Media, Culture \& Society 21(5):601-626.

Baumann, Shyon. (2007). "A General Theory of Artistic Legitimation: How Art Worlds are Like Social Movements.” Poetics: 35(1): 47-65. 
Becker, Howard Saul. 1982. Art Worlds. Berkeley: University of California Press.

Berman, Elizabeth Popp. 2006. "Before the Professional Project: Success and Failure at Creating an Organizational Representative for English Doctors." Theory and Society 35(2):157-191. Bernstein, Elizabeth. 2007. Temporarily Yours: Intimacy, Authenticity, and the Commerce of Sex. Chicago: University of Chicago Press.

Beveridge, Karl. 2005. “The Hidden Costs of Public Exhibitions: Artists donate \$4,000,000 a year to the costs of public exhibitions in Canada for preparation and installation work." Calendar (CARFAC), 4-5.

Biernacki, Richard. 1995. The Fabrication of Labor: Germany and Britain, 1640-1914. Berkeley: University of California Press.

Binder, Amy. 1993. "Constructing Racial Rhetoric: Media Depictions of Harm in Heavy Metal and Rap Music." American Sociological Review 58(6):753-767.

Bourdieu, Pierre. 1993. The Field of Cultural Production: Essays on Art and Literature. Cambridge, England: Polity Press.

Bradley, Will, and Charles Esche, eds. 2007. Art and Social Change: A Critical Reader. London: Tate Publishing.

Bryan-Wilson, Julia. 2009. Art Workers: Radical Practice in the Vietnam War Era. Berkeley and Los Angeles: University of California Press.

Bourdieu, Pierre. 1993. The Field of Cultural Production: Essays on Art and Literature.

Cambridge: Polity Press.

Canadian Artists' Representation. 1975a. "Saint Mary's University Art Gallery Unfair to Artists." CAR GO, 13.

Canadian Artists' Representation. 1975b. "CAR Fee Schedul.” CAR News, 2.

Canadian Artists' Representation. 1978. "Proposals for the Reform of Copyright Law in

Canada." CARFAC News, 7-24.

Canadian Artists' Representation. 1983. "CARFAC Recommended Minimum Exhibition Fee Schedule for April 1, 1983." CARFAC News.

Caves, Richard E. 2000. Creative Industries: Contracts Between Art and Commerce. Cambridge: Harvard University Press.

Chambers, Jack. 1973. “Encounters.” Canadian Artists' Representation National Newsletter, 3846.

Chambers, Jack, Kim Ondaatje, and Tony Urquhart. 1973. “C.A.R.....?” Canadian Artists'

Representation National Newsletter.

Cowen, Tyler, and Alexander Tabarrok. 2000. "An Economic Theory of Avant-Garde and

Popular Art, or High and Low Culture." Southern Economic Journal 67(2):232-253.

Crean, Susan et al. 1978. "The Artists." CARFAC News, 4-9.

Daniels, Arlene Kaplan. 1987. "Invisible Work.” Social Problems 34(5):403-415.

Durkheim, Emile. 1984. The Division of Labor in Society. New York: Free Press.

Favell, Adrian. 2012. Before and After Superflat: A Short History of Japanese Contemporary Art 1990-2011. Blue Kingfisher Limited.

Fine, Gary Alan. 1996. "Justifying Work: Occupational Rhetorics as Resources in Restaurant Kitchens.” Administrative Science Quarterly 41(1):90-115.

Fine, Gary Alan. 2003. "Crafting Authenticity: The Validation of Identity in Self-Taught Art." Theory and Society 32(2):153-180.

Fleet, Vanessa and Gabrielle Kemp. 2006. "The Art of Fundraising." CARFAC Calendar, 6-7. 
Fourcade, Marion. 2011. "Cents and Sensibility: Economic Valuation and the Nature of 'Nature'." American Journal of Sociology 116(6):1721-77.

Friedland, Roger, \& Alford, Robert R. (1991). "Bringing Society Back In.” In Walter W. Powell \& Paul J. DiMaggio (Eds.),

Symbols, Practices, and Institutional Contradictions: The New Institutionalism in Organizational Analysis. Chicago: University of Chicago Press.

Frutkin, Mark. 1987. "Copyright: From Beginning to End." Art Action, 2-3.

Gamst, Frederick C. 1995. "Considerations of Work." in Meanings of Work: Considerations for the Twenty-First Century, edited by Fredrick C Gamst. Albany: State University of New York Press.

Gibbon, Heather M. Fitz. 1987. "From Prints to Posters: The Production of Artistic Value in a Popular Art World." Symbolic Interaction 10(1):111-128.

Glaser, Barney G, and Anselm L Strauss. 1967. The Discovery of Grounded Theory: Strategies for Qualitative Research. Chicago: Aldine Pub. Co.

Graham, Jim. 2002. "Status of Artist Legislation Jumps Into Prominence." Calendar (CARFAC), $1-4$.

Harrison, Charles, and Paul Wood, eds. 2003. Art in Theory 1900-2000: An Anthology of Changing Ideas. Malden, MA: Blackwell.

Healy, Kieran Joseph. 2006. Last Best Gifts: Altruism and the Market for Human Blood and Organs. Chicago: University of Chicago Press.

Hirsch, Paul M. 1972. "Processing Fads and Fashions: An Organization-Set Analysis of Cultural Industry Systems." The American Journal of Sociology 77(4):639-659.

James, Geoffrey. 1978. “Copyright \& You.” CARFAC News, 7-24.

Jones, Candace, and Reut Livne-Tarandach. 2008. "Designing a Frame: Rhetorical Strategies of Architects.” Journal of Organizational Behavior 29(8): 1075-1099.

Kwon, Miwon. 2004. One Place after Another: Site-Specific Art and Locational Identity. The MIT Press.

Lang, Gladys Engel, and Kurt Lang. 1988. "Recognition and Renown: The Survival of Artistic Reputation." The American Journal of Sociology 94(1):79-109.

Macdonald, Cameron Lynne. 2010. Shadow Mothers: Nannies, Au Pairs, and the Micropolitics of Mothering. Berkeley: University of California Press.

Markusen, Ann. 2013."Artists Work Everywhere." Work and Occupations 40(4): 481-495. Menger, Pierre-Michel. 2014. The Economics of Creativity: Art and Achievement under Uncertainty. Cambridge, Massachusetts: Harvard University Press.

Messias, Deanne K. Hilfinger et al. 1997. "Defining and Redefining Work: Implications for Women's Health." Gender and Society 11(3):296-323.

Miles, Matthew B, and A. M Huberman. 1994. Qualitative data analysis : an expanded sourcebook. Thousand Oaks: Sage Publications.

Organisation for Economic Co-operation and Development. 2005. Growth in Services: Fostering Employment, Productivity and Innovation. 2, rue André-Pascal, 75775 Paris.

Perreault, John. 1969. “Untitled statement.” P. 120-21 in Open Hearing. New York: Art Workers' Coalition.

Rao, Hayagreeva, Philippe Monin, and Rodolphe Durand. 2003. "Institutional Change in Toque Ville: Nouvelle Cuisine as an Identity Movement in French Gastronomy" American Journal of Sociology 108(4): 795-843. 
Sherman, Rachel. 2010. “'Time Is Our Commodity': Gender and the Struggle for Occupational Legitimacy Among Personal Concierges." Work and Occupations 37(1):81-114.

Singerman, Howard. 1999. Art Subjects: Making Artists in the American University. Berkeley: University of California Press.

Tateishi, Susan Alter. 1985. "The House that Jack Built: fifteen years later." CARFAC News, 26.

Thornton, Patricia H., and William Ocasio. 1999. "Institutional Logics and the Historical Contingency of Power in Organizations: Executive Succession in the Higher Education Publishing Industry, 1958-1990." American Journal of Sociology 105(3):801-843. Thornton, Patricia H. 2004. Markets from Culture: Institutional Logics and Organizational Decisions in Higher Education Publishing. Stanford University Press.

Thornton, Patricia H., Candace Jones, and Kenneth Kury. 2005. "Institutional Logics and Institutional Change in Organizations: Transformation in Accounting, Architecture, and Publishing." Research in the Sociology of Organizations 23: 125-170.

Thornton, Patricia H., William Ocasio, and Michael Lounsbury. 2012. The Institutional Logics Perspective. Oxford: Oxford University Press.

Velthuis, Olav. 2003. "Symbolic meanings of prices: Constructing the value of contemporary art in Amsterdam and New York galleries." Theory and Society 32(2):181-215.

Velthuis, Olav. 2004. "An Interpretive Approach to Meanings of Prices." The Review of Austrian Economics 17(4):371-386.

Velthuis, Olav. 2005. Talking Prices: Symbolic meanings of prices on the market for contemporary art. Princeton: Princeton University Press.

Velthuis, Olav. 2013. Talking Prices: Symbolic Meanings of Prices on the Market for Contemporary Art. Princeton: Princeton University Press.

Working Artists and the Greater Economy. 2016. "W.A.G.E." Retrieved April 12, 2016 (http://www.wageforwork.com/).

Weber, Max. 1968. From Max Weber: Essays in Sociology. Oxford: Oxford University Press.

White, Harrison C. and Cynthia White. 1965. Canvases and Careers: Institutional Change in the French Painting World. Chicago: University of Chicago Press.

Yates, Sarah. 1983. "The Applebaum-Hébert Report: An Analysis.” CARFAC News, 2-4.

Zelizer, Viviana A. 1978. "Human Values and the Market: The Case of Life Insurance and Death in 19th-Century America.” American Journal of Sociology 84(3):591-610.

Zelizer, Viviana A. 1981. "The Price and Value of Children: The Case of Children's Insurance." American Journal of Sociology 86(5):1036-1056.

Zelizer, Viviana A. 1989. "The Social Meaning of Money: 'Special Monies'." American Journal of Sociology 95(2):342-377.

Zelizer, Viviana A. 2000. “The Purchase of Intimacy.” Law \& Social Inquiry 25(3):817-848. 